\title{
PROCEEDINGS OF THE CAMBRIDGE PHILOLOGICAL SOCIETY
}

page I D. R. SHACKLETON BAILEY, Emendations of Cicero, 'Ad Quintum Fratrem' and 'Ad Brutum'

7 R. S. BLUCK, The Puzzles of Size and Number in Plato's 'Theaetetus'

9 J. M. COOK, The Problem of Classical Ionia

18 F. R. D. GOODYEAR, Notes on the 'Aetna'

2 I G. T. G RIF FI T H, Some Habits of Thucydides when introducing Persons

34 G. S. KIR K, Dark Age and Oral Poet

49 J. S. MORRISON, Antiphon

59 D. J. MOS LEY, Who 'Signed' Treaties in Ancient Greece?

63 H. D. WESTLAKE, Thucydides Iv, 108, 4

68 D. L. PA GE, Various Conjectures

70 D. R. SHACKLETON BAILEY, Letter to the Editors 